\title{
Making Sense of Shakespeare: a Cultural Icon for Contemporary Audiences
}

\author{
Michael R. Olsson \\ University of Technology, Sydney
}

\begin{abstract}
The works of William Shakespeare are more popular in the $21^{\text {st }}$ century than ever before. Why are theatre and audiences around the globe still drawn to his work? How do they make sense of these texts in ways that resonate with their cosmopolitan, contemporary audiences? This article uses the findings of a study interviewing 35 theatre professionals in Canada, Finland and the United Kingdom to explore these issues. Theoretically and methodologically, it is a bricolage, drawing on a range of approaches including Foucault's discourse analysis, and Hobsbawm's invented traditions to understand participants' sense-making as a social practice. It argues that attempting to understand the significance of a major cultural icon such as Shakespeare in contemporary cosmopolitan civil society needs to recognise the many meanings, roles and significances that surround him and that this complexity makes it unlikely that any one theoretical lens will prove adequate on its own.
\end{abstract}

\section{Introduction}

All the world's a stage, And all the men and women merely players: They have their exits and their entrances; And one man in his time plays many parts (As You Like It)

The works of the English playwright William Shakespeare (1564-1616) have had a profound effect on the world we live in. Words and phrases he coined litter the everyday speech of English speakers around the world (McCrum, 1986). Although considered by some to be the quintessential English playwright, his works are published around the world, not only in English but 80 other languages. Shakespeare's global popularity and prestige in the theatre would also seem to have never been higher. The 2012 World Shakespeare Festival, for example, included performances of his plays in 50 languages (Dickson, 2013).

How is it that a writer who died almost four centuries ago remains such an iconic figure in contemporary cosmopolitan civil society? Why are theatre professionals - actors, directors, designers - and audiences around the globe still drawn to his work? How do theatre professionals, individually and as part of a creative community, make sense of these texts in ways that resonate with their cosmopolitan, contemporary audiences? 
The present article will endeavour to explore these issues through its analysis of the findings of an international study examining how theatre professionals (actors, directors, designers and others) in different countries make sense of the works of a culturally iconic author (William Shakespeare) in the course of performing one of his plays. In doing so, it will not only shed light on the working practices of members of this heterogeneous creative community, but also illuminate aspects of the continuing importance of Shakespeare not just for the English or English speakers but for people around the globe. More broadly, in doing so it may shed light on the nature of people's relationship with information in a $21^{\text {st }}$ century postmodern world.

\section{Methodology}

Though this be madness, yet there is method in 't.

(Hamlet)

The present article draws on the findings of a larger study of theatre professionals' sensemaking (Olsson 2010a; 2010b; 2012). Methodologically, the study was a bricolage, adapting approaches and techniques from a variety of disciplinary traditions, including critical discourse analysis, communication and education, as well as information behaviour/practices research. The approach to both interviewing and analysis was iterative, developing and changing significantly through the course of the study.

The findings of the study are based on interviews with 35 theatre professionals in Canada, Finland and the United Kingdom. Participants include actors, directors, set and costume designers, voice coaches and dramaturges affiliated with a number of theatre companies, including the Stratford Shakespeare Festival of Canada (North America's largest and most prestigious classical repertory theatre), Shakespeare's Globe, the Royal Shakespeare Company, the National Theatre and the Central School of Speech and Drama in the UK and the Tampereen Työväen Teatteri (Tampere People’s Theatre) in Finland. While some participants were purposefully sampled and directly approached by the researcher, the majority (28) were recruited via snowball sampling (Patton, 2002), where participants nominated other theatre professionals (in their own company or elsewhere) they felt should be included in the research. The interviews were carried out face-to-face, usually in informal settings (green room, rehearsal room etc.) at the theatre where the participants worked or in other informal settings, such as cafes or the participant's home. 
One particular challenge of the present study was that many of the participants, especially actors and directors, were very used to being interviewed: publicity and talking to the press being part of their job. This had both positive and negative aspects. These participants were confident and comfortable in talking about themselves, with a ready supply of amusing anecdotes to hand. However, this meant that it was important to develop strategies that probed below the polished surface of these oft-told stories.

The strategy developed was to move away from a semi-structured approach to interviewing and to carry out, longer, more conversational interviews of the kind advocated by Seidman (1991). Even the briefest interview (cut short by the bell for an afternoon matinee) lasted just over an hour, with many running more than two or even three hours. A number of participants commented that they found the interviews a revealing process, offering them an opportunity to reflect on both their professional life and their relationship with Shakespeare in a way they had not done before.

I just want to thank you because I've never had the opportunity to think about my life as an actor in this way before. I think it's going to make me a better actor.

(Seyton, actor)

The interviews were digitally audio-recorded and professionally transcribed prior to analysis. An inductive critical discourse analysis (Fairclough, 2003; Paltridge, 2008) of the interview and follow-up transcripts was undertaken. This process included a detailed micro-analysis of the interview transcripts, aided by the use of NVivo software, with the researcher's field notes and listening to the original audio recordings also used to inform the process. In addition to this micro-analysis, the researcher made extensive use of the broader thematic writing techniques advocated by Glaser and Strauss (1967) to explore emergent trends, concepts and theories. Participants played an active role in the analysis process and were frequently asked to comment on the extent to which emerging patterns and concepts reflected their own experience.

\section{Conceptual Framework}

As, painfully to pore upon a book To seek the light of truth (Love's Labours Lost)

The design of the study and the analysis of the interview data were influenced by theories and approaches from a range of different disciplinary traditions including communication, critical 
discourse analysis and sociology of knowledge, as well as information studies. The analysis of the research described in this article will draw particularly on ideas drawn from Foucault's approach to discourse analysis, including pouvoir/savoir (power/knowledge) and 'Death of the Author' (Foucault, 1980; Rabinow, 1984). It will also critically engage with Hobsbawm’s notion of ‘invented traditions’ (Hobsbawn \& Ranger, 1993).

Shakespeare's iconic status as the greatest playwright that has ever lived would seem, at first glance, to be a perfect example of Hobsbawm's idea:

'Invented tradition' is taken to mean a set of practices, normally governed by overtly or tacitly accepted rules and of a ritual or symbolic nature, which seek to inculcate certain values and norms of behaviour by repetition, which automatically implies continuity with the past. In fact, where possible, they normally attempt to establish continuity with a suitable historic past.

(Hobsbawm, 1993, 1)

Certainly, there is ample evidence to suggest both that Shakespeare's iconic status is more recent than his present pre-eminence might lead one to assume and that there have been long periods when his work was not popular or even publically performed. Although there is evidence to suggest that Shakespeare was well regarded by his contemporaries, such as Ben Jonson, much of this extant commentary focuses on his poetry. Theatre (like television today) was regarded by the Jacobean intelligentsia as an essentially popular and ephemeral medium. Already beginning to go somewhat out of fashion in Shakespeare's own lifetime, the Puritan closure of the theatre during the English Civil War and changing theatrical tastes from the Restoration onwards meant that his plays were largely unperformed for more than 150 years until the late $18^{\text {th }}$ Century. It took the rise of Romanticism - and the rise of Britain as a dominant imperial power in search of a symbol of its cultural superiority - to lay the foundations of the monolithic reputation his work enjoys today. The advent of prestigious theatre companies dedicated to the performance of Shakespeare's work is even more recent: The Royal Shakespeare Company was founded in 1961(Royal Shakespeare Company, 2013), while Shakespeare’s Globe had its first season in 1996 (Shakespeare’s Globe, 2013).

Yet to view Shakespeare's iconic status solely as an example of an invented tradition raises more questions than it answers. If, for example, Shakespeare's rise to pre-eminence can be dated to Britain's rise to imperial power, why has prestige continued to grow as that same empire has dwindled? Why is he not now seen, as other Victorian imperial icons such as 
Milton and Kipling are, as an outmoded relic? Why does performing Shakespeare remain so popular in so many post-colonial contexts, from Australia and Canada to India? Why, as the study's findings will show, is his work venerated in countries that were never part of Britain's imperial orbit, such as Finland and Sweden?

Despite the prevalence of the view of Shakespeare as a 'timeless' genius whose works contains a 'universal' truth, it is clear that every production of Shakespeare is - indeed, must be - different: the product of the sense-making processes of different people, with different beliefs and understandings operating in different organisational/cultural/artistic/national contexts performing in different places for different audiences. Golder and Madelaine (2001), for example, found that the recent Australian productions they examined drew inspiration from sources and issues as diverse as Freudian psychology, Japanese kabuki and the indigenous land-rights debate.

In seeking to examine the working practices by which theatre professionals made sense of Shakespeare, the analysis therefore also made use ideas and approaches drawn from the work of the French historian and philosopher, Michel Foucault (1980; Rabinow, 1984). In Foucault's conception of it, discourses are more than just a way of talking - rather it is seen as a complex network of relationships between individuals, texts, ideas and institutions, with each 'node' impacting on other nodes, and on the dynamics of the discourse as a whole.

Analysis of the study's findings will show that participants' constructions of Shakespeare are the result of complex interactions between the members of the company, the text and an array of prevailing discourses about Shakespeare and performance, some of them international, found in all participants' accounts, some of them specific to a particular national or cultural context.

Like Hobsbawm, Foucault emphasised that any discourse is inextricably tied to its particular socio-historical context and cannot be studied or understood if divorced from this context: "For Foucault there is ... no universal understanding that is beyond history and society" (Rabinow, 1984, 4). However, Foucault also recognised that discourses are never static: the dynamics of people's ongoing engagement with them means they are in a continuous process of contestation, re-affirmation and re-invention: 
There is a battle 'for truth' or at least 'around truth' - it being understood once again that by truth I do not mean 'the ensemble of truths which are to be discovered and accepted' but rather 'the ensemble of rules according to which the true and the false are separated and specific effects of power attached to the true. (Foucault, in Rabinow (ed.), 1984, 418).

The ongoing relations between people, institutions and texts generate regimes of both meaning and authority (power/knowledge) simultaneously. In this view, the creation and dissemination of 'texts', the 'weighting' of one 'text' more than another, involves a series of dynamic power relations. These relations are constantly re-inventing and re-affirming themselves through the process of applying the discursive rules to examine new 'texts' and to re-examine existing ones.

As a consequence, a Foucauldian lens must lead us to question one of Hobsbawm's central assumptions. Implicit in the notion of 'invented tradition' is the implicit assumption that there is such a thing as an authentic i.e. non-invented tradition; Foucault's work is likely lead us to the view that traditions, however old, however continuous, are discursive constructs and that contemporary engagements with them must inevitably involve a degree of re-invention. It is simply not possible, for example, for a $21^{\text {st }}$ century reader or performer to understand Shakespeare's work in the way that his Jacobean contemporaries did - the sense we make of it is inevitably coloured by our own discursive context.

The findings suggest that one reason for Shakespeare's continuing popularity, the continued performance of his plays around the world, may not be, as in popular wisdom, their universality but their mutability - the ability of theatre professionals to continually re-invent the plays, giving them new meanings for increasingly cosmopolitan contemporary global audiences. The study has sought to explore the interplay of how these diverse constructions as well as the sometimes convergent, sometimes divergent interests of actors, directors, designers and technicians - interact in the cooperative environment of producing a theatrical production. 


\title{
Findings
}

There are more things in heaven and earth, Horatio,

Than are dreamt of in your philosophy.

(Hamlet)

The study's findings produced a very rich picture of the information practices the participants engaged in to make sense of Shakespeare - a portrait in many ways at odds with the assumptions underpinning prevailing approaches to information behaviour research. In particular, they highlighted the essentially social nature of the participants' knowledge acquisition, not only in their heavy reliance on personal relationships but also in the clear relationship between their sense-making and the social norms and accepted practices (discursive rules) that have developed in the theatre world over many generations.

\section{Audience - the Silent Partner}

\author{
But pardon, and gentles all... \\ And let us, ciphers to this great accompt, \\ On your imaginary forces work... \\ For 'tis your thoughts that now must deck our kings, \\ Carry them here and there; jumping o'er times, \\ Turning the accomplishment of many years \\ Into an hour-glass \\ (Henry $\mathrm{V}$ )
}

Theatre professionals' interpretations of Shakespeare are social in a very literal way.

Underpinning all participants' accounts was an understanding that they needed to make sense of Shakespeare not only for themselves or their colleagues but rather they needed to do so in a way that would make sense for their audience:

It's really about building that connection - it's like a dialogue between you and them ... And sometimes you won't know what works until you are actually in front of an audience. (Hippolyta, actor)

Furthermore, many of the theatre companies involved in the study routinely perform to heterogeneous, multi-cultural audiences. It was clear from participants' accounts that they understood that different backgrounds and experiences would make sense of their performance in different ways:

Here at the Globe our audience is so different - you've got tourists from all over the world, with varying degrees of English ...you've also got your serious Shakespeareans... some of them have seen everyone from Olivier and Burton to Branagh... at the same time you've also got your school groups. You've got to find a way to connect with all of them on some level. (Mercutio, actor) 
The challenges of an international audience were also evident in Canada:

We need to be Canadian - but not too Canadian! We're a government funded company and like to think of ourselves as the national company - but then quite a lot of our audience come from over the border. So if we make the references too specific - if the clown characters all sound like they're from Newfoundland, eh? - we'll lose the Americans! (Rosalind, voice coach)

In describing these challenges, participants demonstrated their appreciation of Shakespeare as an icon whose power extends well beyond their own particular professional and cultural contexts, as well as an awareness that his work - and their performance- will have different meanings for different people interpreting him through their own cultural lenses.

The challenge for a contemporary theatre company - and for individual theatre professionals - is therefore to simultaneously meet the multiple and sometimes conflicting expectations of a cosmopolitan audience: that they will see a performance that is relevant and accessible yet at the same time connected to the iconic Shakespearean tradition.

\section{The Battle for Truth}

Once more unto the breach, dear friends

(Henry $V$ )

Meeting this challenge of connecting to an iconic tradition was at the heart of the professional creative lives of all the study's participants. It was a subject that all participants had thought deeply and cared passionately about. For many, it was a question they had literally dedicated their lives to. In speaking with the researcher about Shakespeare, it was clear that although participants held a variety of opinions, they did not make sense of his work in an idiosyncratic way. Instead, the views they expressed were explicitly related to discourses that were well established in the theatre world. Participants' accounts were eloquent and well thought out, the distillation of years of professional endeavour and showed a strong awareness of being part of a long-standing theatrical tradition of enormous cultural importance.

These discourses provided a framework - or rather a set of frameworks - that participants, both individually and as a part of a working community, engaged with. Participants did not blindly accept prevailing discourses, nor were their sense-making processes dominated by a single discourse: all participants engaged with them selectively, critically and strategically. Their accounts demonstrate that Foucault's 'battle for truth' is not only a macro-sociological 
phenomenon: it is integral to micro-sociological interactions between community members and even the thought processes of individuals.

Perhaps the most striking feature of participants' accounts of their relationship with Shakespeare is that, without exception, every participant drew on two essentially contradictory discourses.

\section{Authenticity Discourse}

Speak the speech, I pray you, as I pronounced it to you, trippingly on the tongue

(Hamlet)

The first of these, allied to the long-standing tradition of viewing Shakespeare as a 'universal genius', valued authenticity:

I feel it's a great honour and a great responsibility to do this work in an authentic way: to be true to Shakespeare's language ... these characters... Shakespeare is bigger than all of us. (Robin Goodfellow, Actor)

This is a discourse focussed on divining authorial intent: that the plays have a 'true' meaning and the role of theatre professionals is to represent this faithfully:

I often ask myself "What did Shakespeare mean here?" His characters have such depth, are so well written... My job is to bring them to life. (Viola, actor)

Related to this was a widely expressed view that saw theatre professionals as having a special insight into the work's 'true meaning:

You know, I don’t think you can really understand Shakespeare, until you perform it ... the plays were written to be performed, not read. (Ned Poins, actor)

In using this discourse, some participants put forward the view that theatre professionals are the ‘true custodians' of Shakespeare's legacy often explicitly contrasting this with academic approaches:

I just can't stand it when they go on about 'death of the author'- I want to find that connection to Shakespeare... (Mistress Quickly, actor)

In a few cases, participants supported this by reference to theatrical tradition:

It's kind of amazing to think of yourself as being part of a tradition that goes back through the centuries ... to Shakespeare and the Globe. And I think you feel a responsibility to carry on that tradition, to honour it. (Antony, actor) 
While present, reference to this kind of Hobsbawmian invented tradition was not the primary discursive practice that participants referred to. Instead, their accounts emphasised the importance of a close reading of the text, often combined with the rehearsal room interactions described above, as a way of uncovering their true meaning:

When I'm working on the play, I feel I'm really coming to understand Shakespeare ... I sometimes feel like he’s talking directly to me. (Tamora, actor)

Perhaps the ultimate expression of this authenticity discourse was a highly sophisticated set of practices for reading employed by some participants both at the Globe and at Stratford in Canada. This 'Shakespeare as Director' discourse, which focusses on a close reading of punctuation, stage directions and other cues in the First Folio and early Quartos, essentially argues that instructions on how to perform Shakespeare are integral to the structure of the text:

Shakespeare actually tells you how to speak the lines! If you look at the blank verse, it shows you when to pause, what to give emphasis to ... He does the work for you... (Rosencrantz, actor)

Shakespeare is such a master of language. If you listen to the sound of the words, he uses the sound of the words to convey the emotion... He even uses punctuation to tell you where to take a breath. (Ned Poins, actor)

The participants who discussed this approach (all classically trained actors) demonstrated an extraordinary knowledge of the texts they described and a depth of analysis at least the equal of anything to be found in the academy.

\section{Creativity Discourse}

O for a Muse of fire, that would ascend The brightest heaven of invention

(Henry V)

At the same time, all participants' accounts showed an understanding that interpretations of Shakespeare had changed over time, and that their adaptability was a key feature of their enduring popularity:

The reason that this stuff has lasted for as long as it has is .... that there are as many different ways of interpreting it as there are people coming to it.

(Hippolyta, actor)

In using this creativity discourse, participants explicitly related this to the high value theatre professionals place on originality: 
I don't want to just copy what's been done before. I need to make the part mine... find my own truth. (Mercutio, actor)

Drawing on this discourse, each participant would strive to bring something "new and fresh" to each new production:

We wanted to make this production very political, quite Marxist...Show

Shakespeare in a new way, different to what the audience expects (Puck, actor)

You need to find new settings, new approaches to the design ... get away from 'pumpkin pants' Shakespeare! (Sebastian, designer)

Allied to this discourse, is a concern with making the plays relevant to a contemporary audience:

How do you get across the idea of what royalty means to a modern audience? I mean they weren't nice polite guys cutting ribbons ... They were more like mafia dons! (Rosalind, voice coach)

\section{A Servant of Two Masters?}

We came into the world like brother and brother, And now let's go hand in hand, not one before another

(Comedy of Errors)

These two discourses of authenticity and creativity are frequently in opposition in participants' accounts, with the one being used to critique the other:

On one level, it's interesting and kind of cool to delve into what people in Shakespeare's time believed about ghosts - stuff like that... but at the same time, I have to say that doesn't really help you get out and connect with a front row full of teenagers! (Laertes, actor)

Well we have a director now, he's very focussed on the look of the thing, making a big spectacle, but to me that's going against what Shakespeare is about - the characters, the language... (Antony, actor)

It would be a mistake to see participants' use of two apparently contradictory discourses as a 'problem', some failure on their part to comprehend the 'truth'. Discourse analytic scholars have long understood that complex topics will invariably give rise to multiple discourses and that individuals will move between these discourses as circumstances dictate.

Furthermore, it is clear from the study that this apparent paradox is not a weakness but a strength. Were the 'authenticity' discourse to be dominant, the likely outcome would be theatre that was simply an exercise in historical recreation, of interest to only a few scholars. 
Conversely, a production where the 'creativity’ discourse was pre-eminent might be rejected by the audience (as avant-garde productions frequently have been) as 'not Shakespeare'. The competing claims of these two discourses frame the 'battle for truth' (Foucault) within each production. It is the creative tensions between their competing claims that make each new production both unique and connected to iconic tradition.

\section{National Voices}

Cry 'God for Harry, England, and Saint George!

(Henry V)

Nowhere was the battle between the creativity/contemporary relevance and authenticity discourses clearer than in the extensive discussion of accent by both Canadian and UK participants:

There's a lot of argument here as to whether you should say "the duke” ... or "the dook". (Rosalind, voice coach)

In both countries, there were a number of participants, both actors and directors, who wanted to move away from the Received Pronunciation (BBC/public school English) of 'traditional' Shakespearian productions to use accents more like the everyday speech of the audience:

I don’t see why an Ancient Greek character needs to sound like he went to Eton! (Zero, director)

As in the above example, three UK participants talked about the accent issue in terms of class:

I want the kids from Brixton - or Glasgow! - to feel that Shakespeare's for them too ....it’s not just posh gits with lah-de-dah accents! (MacMorris, actor)

In both countries, the discussion of accent could be seen as drawing on the 'Creativity' discourse - the auditory equivalent of the shift away from 'pumpkin pants' costumes -a strategy to distance the production from traditions that were seen as outmoded and alienating for contemporary audiences.

Contemporary accents, some also argued, not only made the characters more accessible to the audience but could be used to convey meaning:

One of the best productions I've seen was a Romeo and Juliet from Quebec... the Capulets were Francophone and the Montagues were Anglophone... (Rosalind, voice coach) 
I've loved seeing a First Nations actor playing Shylock - I think that's really brought the racism home to people. (Iago, director)

Interestingly, the authenticity discourse could also be employed to justify the shift away from Received Pronunciation (RP):

We had a talk from a language professor from England and he said that the accent in Shakespeare's time would have sounded much more like Americans then RP... (Antony, actor)

After all, RP is a $19^{\text {th }}$ Century invention, Shakespeare wouldn't have even understood it! (Zero, director)

Two Scottish participants made a similar argument, arguing that the Scots voice is not only more authentically Elizabethan, but much more effective at conveying powerful emotion to the audience than the smooth, polished sound of RP:

The language works so much better in Scots - it's more raw, visceral ... and there is a much greater range of sounds... and it's a much more Elizabethan sound! (Ned Poins, actor)

Their spontaneous performance of various speeches to demonstrate this were not only convincing but mesmerising - in a way that no words on a page can convey!

The use of different accents, as with non-traditional costumes or stage settings, is a material example of the tools theatre professionals use to re-invent the iconic Shakespeare authorconstruct (Foucault in Rabinow, 1984). While on the one hand, these innovations challenge certain features of the Shakespearian invented tradition, on the other, by presenting Shakespeare in a new light, by making explicit connections between his work and social/cultural contests and practices the audience can relate to, they actually serve to reinforce the central tenet of the tradition: that Shakespeare is a genius whose work speaks to all people and all times.

The idea of Shakespeare as a specifically English writer was raised as an issue only by two Canadian participants. When asked about this in a follow-up one responded:

Maybe that's seen as an issue here not just because of our history and being part of the Commonwealth but because of our theatre tradition. Tyrone Guthrie (prominent English actor and director) was the first Artistic Director at the Stratford Festival and so many Canadian actors went to England for their training. (Rosalind, voice coach) 
An American-born and educated participant made an interesting comment in relation to this:

You know I never really heard of this idea of Shakespeare as English and that being a problem until I came to Canada. ...in the States we've never had a problem seeing Shakespeare as ours! (Antony, actor)

A Finnish participant made a similar comment:

I don’t think I think of Shakespeare as being English - I mean I don't see Sophocles as only for Greeks! These writers are for the world. (Dionyza, dramaturge)

Shakespeare in Translation

What country, friend, is this?

(Twelfth Night)

The large majority of the study's interviews were carried out in English-speaking countries with participants for whom English is their first language. Nonetheless, there was more discussion of non-English language Shakespeare than might have been anticipated. Much of this discussion drew on the creativity discourse:

I think a lot of the most exciting Shakespeare I've seen in the last ten years has come out of Asia. I saw an Indian [Midsummer Night's] Dream that just blew me away! It was like nothing I'd ever seen. (Orsino, designer)

Japanese directors seem to have a great sense of social distinctions that shape the characters actions. Maybe they are closer to that kind of hierarchy than we are now. (Iago, director)

Some of this discussion was based on a belief that performing in other languages offered more creative freedom:

You know, in many ways I envy my overseas colleagues who get to work with Shakespeare in translation, because they don't have to worry about the problems of archaic language that audiences can't understand ... but we're all "You can't change it, it’s SHAKESPEARE!” (Andromache, dramaturge)

The study did, however, also include four Finnish participants (two actors, a dramaturge and a director), all highly experienced and critically acclaimed. All four had performed Shakespeare in Finnish, while two had also been involved in Swedish-language productions. This provided some insight into how making sense of and performing Shakespeare in another language might be different from, as well as similar to, doing so in English, at least in a Nordic context. 
A striking feature of English language participants' accounts is the extent to which they embraced a view of Shakespeare as the greatest writer who has ever lived. Perhaps this was not only a reflection of Shakespeare's iconic place in English-language culture but also that the great majority of participants worked for companies, such as the Globe and the RSC, where Shakespeare was their raison d'etre. The Finnish participants tended to a slightly different view:

For us perhaps Shakespeare is not the only one but he is one of the greats ... every actor wants to perform the great roles - Hamlet, Macbeth, Lear... (Puck, actor)

Nonetheless, all four participants' enthusiasm for Shakespeare was striking and much of their discussion of his work closely mirrored that of English language participants:

There is no one like him ... not even Ibsen or Chekhov produce such characters! (Fortinbras, actor)

One participant put forward an explanation for Shakespeare's importance in a Finnish context (a view shared by a Finnish drama academic I consulted):

...because of our history - ruled by Sweden, then by Russia, there was not so much written - published in Finnish before independence. And so translating Shakespeare into Finnish has become a kind of measure of the language... when a new translation comes out, it shows us how the language has developed... and it shows that Finnish can be a language for great poetry. (Dionyza, dramaturge)

This is a striking example of the fact that in addition to global discourses around Shakespeare as an author-construct (Foucault in Rabinow, 1984), that such an iconic figure will also take on particular meanings and significnaces unique to particular cultural contexts.

Another potentially important issue that the study provides only a glimpse of is the differences in meaning that arise when a play is translated into one language rather than another. Both participants who performed in both Finnish and Swedish commented on this:

At first we were performing in Swedish but then when we were performing in Finnish, it became like a different play! The emotions were different ... the audience didn't see it the same way ... we had to make changes... (Nerissa, director) 
Such a small relevant sample means that the present study provides only a small glimpse of the complex issue of translation as a shaper of meaning.

\section{Conclusion}

But that's all one, our play is done,
And we'll strive to please you every day.
(Twelfth Night)

The findings of this study provide us with some significant insights, not only into the meaning and significance of Shakespeare in the $21^{\text {st }}$ century but also into the nature of collective creative endeavour and social sense-making. In doing so, the study also provides a microcosm which may provide insights about the nature of meaning in contemporary cosmopolitan civil society.

The findings suggest that attempting to understand the significance of a major cultural icon such as Shakespeare in contemporary cosmopolitan civil society needs to recognise the many meanings, roles and significances that surround him: Shakespeare in the $21^{\text {st }}$ century is not a single monolith but a multitude of continually evolving author constructs. Such complexity makes it unlikely that any one theoretical lens will prove adequate on its own. This article has therefore endeavoured to use several theoretical approaches in order to see what insights different lenses might provide.

Hobsbawm's concept of invented traditions, while problematic in some of its implicit assumptions, is valuable in highlighting the need to critically examine the historical underpinnings of even the most apparently venerable and august of cultural icons. It reminds us that the past is not simply another country: it is a narrative that is continually being rewritten, reconceptualised through the lens of our own societal values and its authority coopted to supported contemporary social and political agendas. It demonstrates that the ability of different institutions - schools, universities, museums, theatre companies - to shape the ways we see and the stories we tell about the past, and people and events from previous eras, will have much broader consequences in terms of the way we see the world we live in.

On one level, the study can be seen as a micro-sociological case study of Foucault's concepts of discourse and power/knowledge - manifested not on the broad canvas of history but in the everyday working practices of the participants. For all that participants evinced a sincere 
desire to perform 'authentic' Shakespeare, their sense-making of his work was clearly an ongoing process of social construction, involving engagement and negotiation not only with their immediate colleagues in the company but long-standing discourses, conventions and established social practices in the theatrical episteme.

The complexity of the discursive landscape that participants negotiated, with its mixture of local, national, and global discourses, brings to mind Baudrillard's (1994) view of the postmodern world as a complex sea of interacting signs and simulacra. Participants' accounts would certainly seem to support the postmodern view that in contemporary society no text has only one meaning or significance. Consequently, as social researchers, when we encounter contexts where a group or institution seeks to assert a single truth, we might usefully follow Fairclough (2003) in questioning whose interests are served by such an assertion and whose are marginalised.

The study's findings suggest that a variety of discourses, even contradictory ones, around an iconic figure such as Shakespeare should not be a source of concern. Foucault's work suggests that such a multiplicity of meanings is the inevitable consequence of the dynamics of discourse. As contemporary civil society grows ever more globally connected, as each of us engages with more and more ideas and debates from around the world, this process can only accelerate. The present study, however, suggest that this phenomenon can have many positive outcomes: that audiences around the globe continue to be entertained and inspired by performances of Shakespeare precisely because they are the product of this dynamic ongoing process of reinvention.

\section{References}

Baudrillard, J. 1994, Simulacra and Simulation, The University of Michigan Press, Ann Arbor.

Fairclough, N. 2003, Analysing discourse: textual analysis for social research, Routledge, London.

Foucault, M. 1980, Power/Knowledge: Selected Interviews and Other Writings 1972-1977, Harvester Press, London.

Glaser, B.G. \& Strauss, A.L. 1967, The Discovery of Grounded Theory: Strategies for Qualitative Research, Aldine Publishing Corporation, New York.

Golder, J. \& Madelaine, R. 2001, “To dote on such luggage’: Appropriating Shakespeare in Australia', in Golder, J. and Madelaine, R. (eds) O Brave New World: Two Centuries of Shakespeare on the Australian Stage, Currency Press, Sydney, pp. 1-16. 
Hobsbawm, E. 1993, 'Inventing traditions', in Hobsbawm, E. and Ranger, T. (eds) The Invention of Tradition, Cambridge University Press, Cambridge.

McCrum, R. 1986, The Story of English, BBC, London.

Olsson, M.R. 2010a, The play's the thing: Theater professionals make sense of Shakespeare', Library and Information Science Research vol.32 no.4, pp. 272-280. http://dx.doi.org/10.1016/i.lisr.2010.07.009

Olsson, M.R. 2010b, 'All the World's a Stage - the information practices and sense-making of theatre professionals', Libri, vol. 60, no. 3, pp. 241-251. http://dx.doi.org/10.1515/libr.2010.021

Olsson, M.R. 2012, 'Making Sense of Shakespeare: the social information world of theatre professionals', in Widén, G. and Holmberg, K. (eds), Social Information Research, Emerald, Bingley.

Paltridge, B. 2008, Discourse Analysis, Continuum, London.

Patton, M. Q. 2002, Qualitative Research \& Evaluation Methods (3rd ed.), Sage Publications, Thousand Oaks, CA.

Rabinow, P. 1984, The Foucault Reader, Peregrine Books, Harmondsworth, Middlesex.

Royal Shakespeare Company 2013, History. http://www.rsc.org.uk/about-us/history/

Seidman, I. E. 1991, Interviewing as Qualitative Research: a Guide for Researchers in Education and the Social Sciences. Teachers College Press, New York.

Shakespeare’s Globe 2013, Rebuilding the Globe, http://www.shakespearesglobe.com/aboutus/history-of-the-globe/rebuilding-the-globe Accessed 10 November 2013. 